\title{
Effects of Dexamethasone on Beta-Adrenergic Receptors in Fetal Lung Explants
}

\author{
WILLIAM M. MANISCALCO ${ }^{(27)}$ AND DONALD L. SHAPIRO \\ Division of Neonatology, Department of Pediatrics, University of Rochester School of Medicine, \\ Rochester, New York, USA
}

\begin{abstract}
SUMMARY
The action of beta-adrenergic agonists on pulmonary surfactant secretion requires lung cell membrane beta-adrenergic receptors. In the fetus, the density of beta-adrenergic receptors in lung increases in the latter stages of gestation. The increase in density can also be induced by maternal glucocorticoid treatment. In this study, we measured beta-adrenergic receptors in developing rat lung by (-) $\left[{ }^{3} \mathbf{H}\right]$-dehydroalprenalol (DHA) binding and confirmed the increase in beta-adrenergic receptors late in gestation. To determine if glucocorticoids have a direct effect on fetal lung to regulate beta-adrenergic receptors, we cultured fetal lung explants with dexamethasone. Treated explants had increased DHA binding compared with controls $(138.0 \pm 8.8$ versus $63.2 \pm 5.0$ fmole/ mg membrane protein). Scatchard analysis revealed that the increased DHA binding was due to an increase in maximum receptor number. There was also a significant difference in the dissociation constant of the treated and control explants $(0.85 \pm 0.07 \mathrm{nM}$ versus $0.43 \pm 0.08 \mathrm{nM}$, respectively; $P<0.05$ ), suggesting that the receptors induced by dexamethasone were of lower binding affinity. Cyclohexamide, an inhibitor of protein synthesis, completely eliminated the dexamethasone induced increase in DHA binding. These data indicate that glucocorticoids have a direct effect on fetal lung to increase beta-adrenergic receptor density and that new protein synthesis is required for this effect.
\end{abstract}

\section{Abbreviation}

DHA, dehydroalprenalol

Secretion of pulmonary surfactant by type II pneumocytes is essential for maintenance of alveolar stability after birth. Recent studies of adult type II pneumocytes indicate that surfactant phospholipid secretion is responsive to beta-adrenergic agonists $(3,6)$. With respect to developing lung, acute fetal injection or maternal pretreatment with several beta-adrenergic agonists produces an increased lecithin/sphingomyelin ratio in fetal lung lavage and pressure-volume relationships indicative of increased alveolar surfactant $(1,2,7,12)$. These effects may be dependent on gestational age: beta-adrenergic stimulation of surfactant efflux is most marked in the most mature fetuses (13).

The cellular effects of beta-adrenergic agonists are mediated through specific cell membrane receptors. Both beta- 1 and beta- 2 type receptors have been identified in membrane preparations from adult and developing lung $(9,18,21,24)$. In developing lung, receptor concentration increases in the latter part of gestation, a time of rapid cellular differentiation. Several recent studies have suggested hormonal control of pulmonary beta-adrenergic receptor density in both adult and fetal lung. Cortisol treatment enhanced isoproterenol-induced surfactant secretion in the A549 pulmonary adenocarcinoma cell line (20). In a cultured human lung cell line, hydrocortisone augmented beta-adrenergic receptor synthesis (8). Adrenalectomy of adult rats produced a decrease in pulmonary receptor concentration that was restored with hydro- cortisone treatment (17). In the rabbit fetus, Cheng et. al. (5) found an increase in beta-adrenergic receptors in fetal lung membranes after maternal treatment with betamethasone. Thyroid hormone may regulate postnatal pulmonary beta-adrenergic receptors (23).

We studied the development of pulmonary beta-adrenergic receptors in fetal rat lung. To examine the direct effect of glucocorticoids on lung beta-adrenergic receptors, fetal lung explants were cultured with dexamethasone. These experiments demonstrated: (1) a marked increase in lung beta-adrenergic receptor concentration during development; (2) a direct influence of glucocorticoids on fetal lung beta-adrenergic receptor concentration; and (3) a requirement for protein synthesis in the production of new beta-adrenergic receptors.

\section{MATERIALS AND METHODS}

Animals. Timed gestation pregnant Sprague-Dawley rats were obtained from Charles River Laboratories (Wilmington, MA). Animals were killed by decapitation and tissues removed in the cold.

Beta-adrenergic receptor analysis. Fetal lung, brain, and heart were dissected free from extraneous material, weighed, and minced with fine surgical scissors for $1 \mathrm{~min}$. They were homogenized in a 10-fold volume of $50 \mathrm{mM}$ Tris- $\mathrm{HCl}, \mathrm{pH} 7.7$, at $22^{\circ} \mathrm{C}$ in a glass vessel with a teflon pestle for $1 \mathrm{~min}$ at a setting of 10 with a Caframo stirrer-homogenizer (CSA, Wiarton, Ontario, Canada). The homogenate was transferred to centrifuge tubes and combined with washings of the vessel and pestle. The homogenate was centrifuged for $20 \mathrm{~min}$ at $50,000 \times \mathrm{g}$ at $4^{\circ} \mathrm{C}$, and the pellet was resuspended in a small volume of buffer and rehomogenized as above. It was transferred to a Dounce homogenizer (Wheaton Scientific, Millville, NJ) and further homogenized for $1 \mathrm{~min}$. Receptor assays were performed immediately after the final homogenization. The final tissue dilution was 1:20.

The beta-adrenergic receptor assay was a modification of the technique described by Cabelli et al. (4) using DHA binding to the membrane preparation. Binding assays were performed in a reaction mixture consisting of Krebs-Ringer phosphate, $\mathrm{pH} 7.4$, containing $0.2 \%$ albumin, $200 \mu \mathrm{M}$ sodium metabisulfite, $100 \mu \mathrm{M}$ phentolamine, and $24 \mathrm{nM}$ DHA in a final volume of $0.5 \mathrm{ml}$. The assay was initiated by the addition of $300 \mu l$ of tissue homogenate (6-15 mg tissue) suspended in Krebs-Ringer phosphate, $\mathrm{pH} 7.4$, containing $0.2 \%$ albumin and $200 \mu \mathrm{M}$ sodium metabisulfite to the prewarmed reaction mixture in $12 \times 75$ test tubes. After incubation at $37^{\circ} \mathrm{C}$ with constant low speed shaking for $20 \mathrm{~min}$, the reaction was terminated by adding $2.5 \mathrm{ml}$ of ice cold wash buffer $(50 \mathrm{mM}$ Tris- $\mathrm{HCl}, \mathrm{pH} 7.4,10 \mathrm{mM} \mathrm{MgCl}$ ) to each tube. The contents of the tube were rapidly filtered under constant vacuum through a single Whatman $\mathrm{GF} / \mathrm{C}$ filter (24-mm diameter) that had been prewashed with $24 \mu \mathrm{M}$ alprenolol. The incubation tubes were rinsed twice and the filters washed six times with $2.5 \mathrm{ml}$ aliquots of ice cold wash buffer. The filters were placed directly into glass scintillation vials, scintillation fluid was added to each vial and radioactivity determined. Control tubes containing no tissue were 
included in all experiments. Specific binding was defined as the total amount of DHA bound less the nonspecific radioligand binding. Nonspecific binding was determined by assaying the bound radioligand in the presence of $6 \mu \mathrm{M}( \pm)$ propranolol. Under the conditions employed, specific binding was approximately $40 \%$ of the total DHA bound to the membrane preparation.

Fetal lung explants. Lung organ explants were prepared from 19 day gestation fetal rats as described previously with slight modifications $(10,16)$. Culture medium was Waymouth's MB $752 / 1$ supplemented with $100 \mu / \mathrm{ml}$ penicillin and $100 \mu \mathrm{g} / \mathrm{ml}$ streptomycin, but not containing serum. The explants were placed on lines scratched into $60 \mathrm{~mm}^{2}$ culture dishes and the culture dishes were placed in a sealed chamber, flushed with $95 \% \mathrm{O}_{2}-5 \% \mathrm{CO}_{2}$, and rocked from side to side ( 3 cycles $/ \mathrm{min}$ ). The medium of both control and treated explants was changed daily. At the end of culture $(48 \mathrm{~h})$, the explants were analyzed fresh for protein and receptor concentration. The concentrations of dexamethasone and cyclohexamide used in these experiments gave the maximal response in preliminary studies (data not shown) and were similar to those used in previous studies of lung explants (11).

Protein was determined by the method of Lowry et al. (14) with bovine serum albumin as the standard.

Chemicals. Culture medium was obtained from Grand Island Biologicals (Grand Island, NY). Biochemicals were obtained from Sigma Co., St. Louis, MO. Radiolabeled chemicals were purchased from New England Nuclear (Boston, MA).

\section{RESULTS}

Beta-adrenergic receptor concentration during development. The developmental pattern of beta-adrenergic receptor concentration in lung is shown in Figure 1. For comparison, data were also obtained for brain and heart tissue. In fetal lung, beta-adrenergic receptor concentration increased $2-3$-fold between 19 and 21 days gestation. This was followed by a further increase on the day after

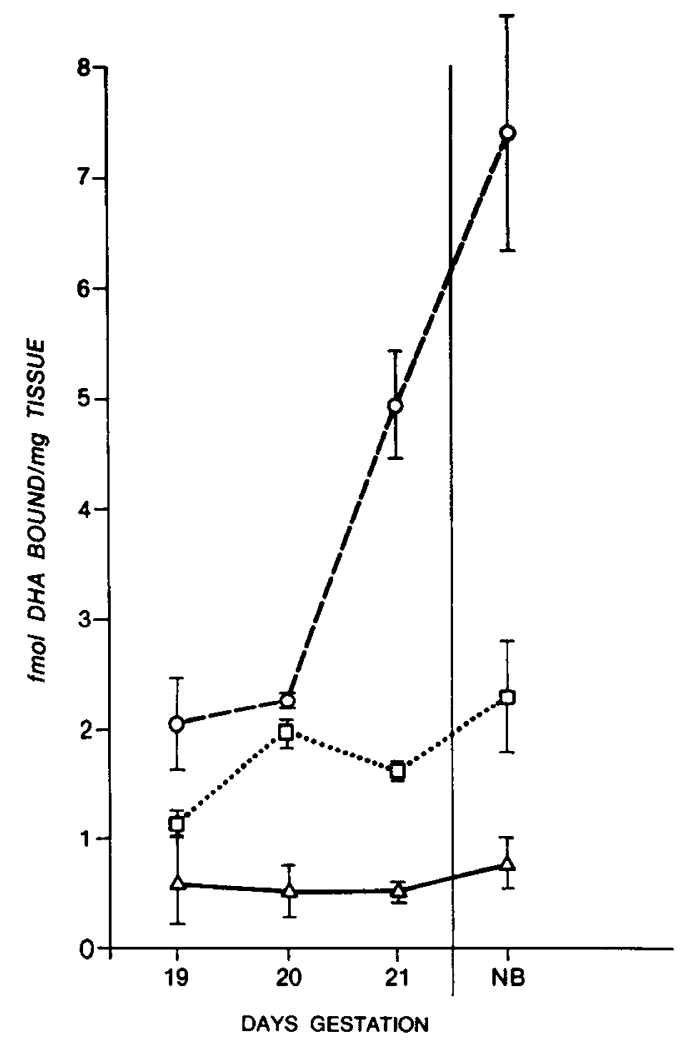

Fig. 1. Beta-adrenergic receptor concentration of heart, lung, and brain during gestation. Points are mean \pm S.E. of three experiments with quadruplicate determinations. Data are expressed as specific DHA binding for lung $(O)$, heart $(\square)$ and brain $(\triangle)$ at the times indicated.

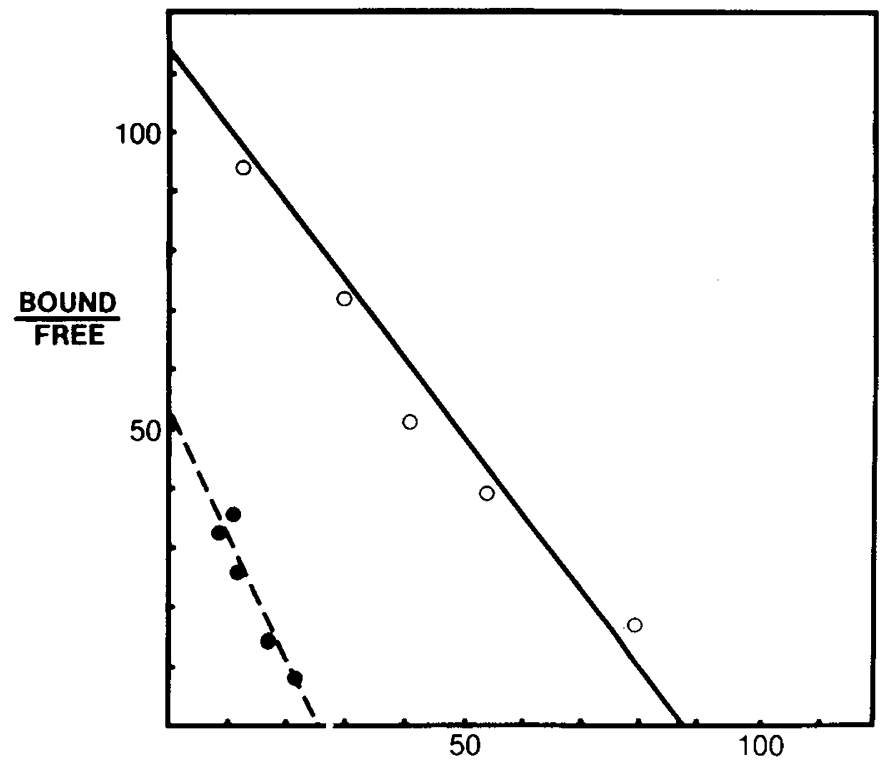

fmoles DHA bound/mg membrane protein

Fig. 2. Scatchard analysis of specific $(-)\left[{ }^{3} \mathrm{H}\right]$-dehydroalprenalol binding to membranes from dexamethasone treated $(O)$ and control $(\bullet)$ fetal lung explants. Each point is the mean of quadruplicate determinations. Lines are best fit plots determined by computer analysis. Dissociation constants were $0.43 \pm 0.08 \mathrm{nM}$ in control and $0.85 \pm 0.07 \mathrm{nM}$ in treated explants.

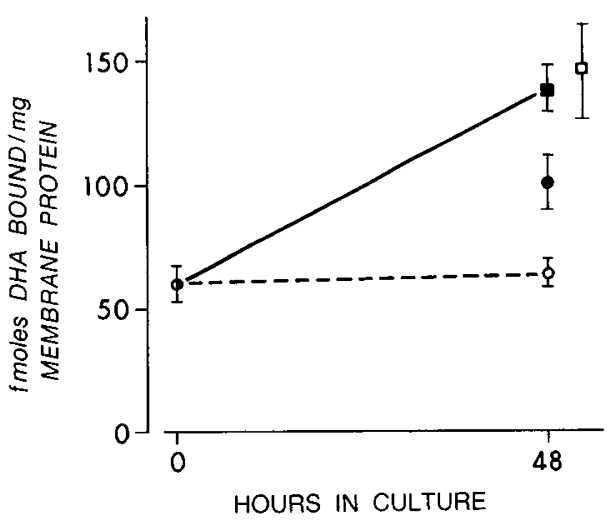

Fig. 3. Effects of dexamethasone on beta-adrenergic receptor concentration in fetal lung explants. Points are means \pm S.E. of 3-5 experiments with quadruplicate determinations. Individual points: fresh 19 day gestation lung (O); control explants after $48 \mathrm{~h}$ in culture without additions (O); explants cultured with $1 \mu \mathrm{M}$ dexamethasone for $48 \mathrm{~h}$ ( $\square$ ) or final 24 h ( $\square$ ) of culture. For comparison, specific $(-)\left[{ }^{3} \mathrm{H}\right]$-dehydroalprenalolbinding of fresh 21 day gestation lung $(\Theta)$ is indicated.

birth. By contrast, beta-adrenergic receptor concentration of brain did not change during this period of development, whereas heart tissue showed some increase in receptor content. This increased pulmonary beta-adrenergic receptor concentration during the late stages of gestation is in agreement with data from others $(9,24)$. There are no comparison data for heart and brain receptors during this developmental period.

Beta-adrenergic receptors in fetal lung explants. Specific DHA binding to a membrane preparation of the fetal lung explants was saturable. Scatchard analysis (Fig. 2) was linear, indicating uniform DHA binding to receptor sites. During the 48-h culture period, specific DHA binding did not increase appreciably compared to the increase seen in vivo at the corresponding gestational ages (Fig. 3). Addition of $1 \mu \mathrm{M}$ dexamethasone to the cultures for $48 \mathrm{~h}$ resulted in an increase in specific DHA binding compared to 


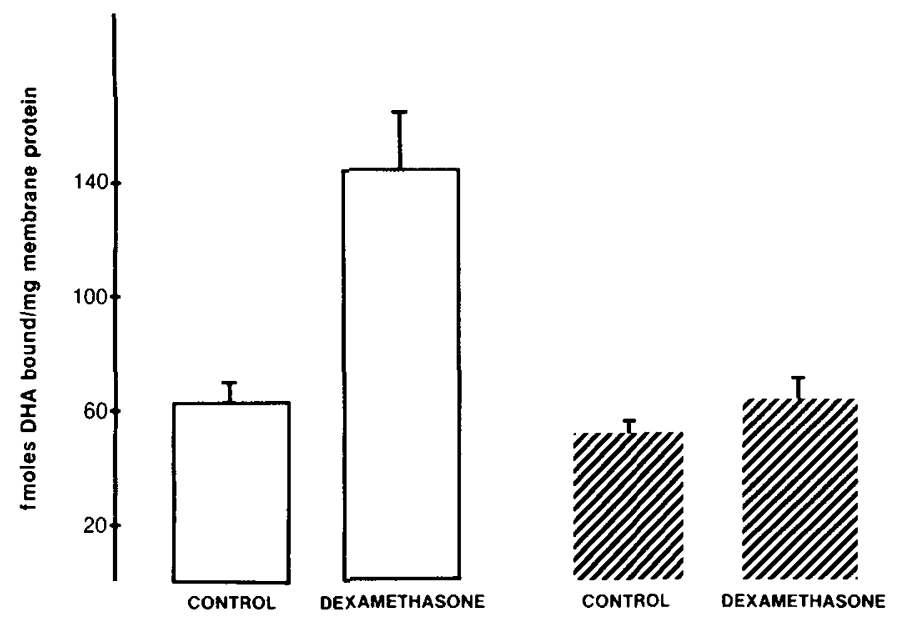

Fig. 4. Effects of cyclohexamide (hatched bars) on dexamethasoneinduced beta-adrenergic receptor concentration. Bars represent mean \pm S.E. of three experiments conducted in quadruplicate. Explants were cultured for $48 \mathrm{~h}$. At $24 \mathrm{~h}, 1 \mu \mathrm{M}$ dexamethasone alone or with $50 \mu \mathrm{M}$ cyclohexamide (hatched bars) was added to some groups.

controls $(138.0 \pm 8.8$ versus $63.2 \pm 5.0$ fmole DHA bound $/ \mathrm{mg}$ membrane protein). An increase of similar magnitude was noted when the dexamethasone was included for only the last $24 \mathrm{~h}$ of culture (Fig. 3), suggesting that the time required for the glucocorticoid effect was less than $24 \mathrm{~h}$. Scatchard analysis of DHA binding in control and treated explants (Fig. 2) revealed that the treated explants had an increased content of receptors, as reflected by the 3-fold increase in extrapolated maximum binding. The dissociation constant $(\mathrm{Kd})$ of the treated explants was significantly greater than controls $(0.85 \pm 0.07 \mathrm{nM}$ versus $0.43 \pm 0.08 \mathrm{nM} ; P$ $<0.05$ ), indicating that the receptors in the treated explants were of lower binding affinity compared to controls. Because DHA binds with equal affinity to beta- 1 and beta- 2 adrenergic receptors, it is not possible to determine from these experiments if the relative concentrations of these subclasses was affected by dexamethasone; thus, the effect of dexamethasone was to induce an increased number of receptors with an average lower binding affinity.

Increases in receptor number can indicate either "up regulation," the exposure of previously unexposed receptors, or synethsis of new receptors. Inasmuch as glucocorticoid effects are frequently mediated by new protein synthesis, we examined the effects of cyclohexamide, an inhibitor of protein synthesis, on DHA binding in the control and dexamethasone treated lung explants. In these experiments all additions to the media were made only for the final $24 \mathrm{~h}$ of culture. Explants cultured in $50 \mu \mathrm{M}$ cyclohexamide only (Fig. 4) had DHA binding at $48 \mathrm{~h}$ that was similar to controls cultured with no additions. This suggests that cyclohexamide was not generally toxic to the tissues. In explants cultured with $1 \mu \mathrm{M}$ dexamethasone plus $50 \mu \mathrm{M}$ cyclohexamide for the final $24 \mathrm{~h}$, there was a blunting of the dexamethasone-induced increase in receptor density. These data indicate that new protein synthesis is required for the dexamethasone effect on beta-adrenergic receptors.

\section{DISCUSSION}

The increased beta-adrenergic receptor concentration of fetal lung, demonstrated in this and other studies $(9,24)$, occurs at a time of rapid cellular differentiation of the fetal lung and development of the surfactant system $(15,22,25)$. Several lines of evidence suggest that beta-adrenergic agonists augment surfactant secretion or synthesis in fetal lung $(1-3,6,7,12)$. Gestational agedependent increases in beta-adrenergic receptor concentration may account for the relative lack of response to these agonists in the immature fetus (13). The increase in beta-adrenergic receptors during gestation is thought to be due to increased receptor number rather than increased binding affinity (9); both beta-1 and beta- 2 subclasses increase with advancing gestation (24).
The cellular distribution of beta-adrenergic receptors in fetal lung is not known. In adult lung, isolated type II pneumocytes respond to beta-adrenergic agonists with increased surfactant secretion, implying that these cells possess beta-adrenergic receptors. Evidence documenting these receptors on membranes from isolated adult type II pneumocytes has been reported (19).

The factors that regulate lung beta-adrenergic receptor density during development are not precisely known, although glucocorticoids and thyroid hormone have been implicated $(5,23)$. Using an explant model of fetal lung, we have documented a direct effect of dexamethasone on beta-adrenergic receptor number. Previous studies, in which pregnant rabbits were injected with glucocorticoids, could not specify a direct effect on fetal lung, because countervalent hormonal and metabolic responses to treatment were not known. Our finding that control explants had no increase in beta-adrenergic receptors whereas explants treated with dexamethasone had increased receptor concentration similar to that of fresh tissue suggests that glucocorticoids may also induce receptors in vivo. Further evidence that glucorcorticoids participate in regulating pulmonary beta-adrenergic receptors in vivo is suggested by finding a decrease in receptor concentration in adrenalectomized animals that was reversed by exogenous hydrocortisone treatment (17).

In the present study, the predominant effect of glucocorticoid treatment was an increase in beta-adrenergic receptor number. This concurs with results of other studies in fetal (5) and adult lung (17). In agreement with studies of Mano et al. (17) in adult lung, we found a decrease in receptor binding affinity for DHA after glucocorticoid treatment. Other studies in fetal lung showed no change in binding affinity after glucocorticoid treatment (5). The decrease in receptor affinity of the explants cultured in glucocorticoid suggests induction of a different class of receptors from those which predominate in untreated explants.

The molecular basis for increased beta-adrenergic receptor concentration in glucocorticoid-treated lung is suggested by this and other studies. In a cultured human cell line, glucocorticoids produced an increased rate of receptor synthesis that resulted in a higher steady state of membrane receptor concentration within 24 h (8). In the present study the glucocorticoid effect was largely eliminated in explants also cultured in cyclohexamide, an inhibitor of protein synthesis. This suggests that the increase in receptor number induced by dexamethasone required new protein synthesis.

The distribution among the various fetal lung cells of betaadrenergic receptors is entirely speculative. The fetal lung is composed of a heterogeneous population of cells, and the specific cellular site of the beta-adrenergic receptors induced by glucocorticoids cannot be defined from this or the previous studies. Because mature type II pneumocytes possess beta-adrenergic receptors, and glucocorticoids induce maturation of other aspects of type II cell function in fetal lung, a likely site of the glucocorticoid induced receptors is the differentiating type II cell.

\section{REFERENCES AND NOTES}

1. Abdellatif, M.M. and Hollingsworth, M.: Effect of oxotremorine and epinephrine on lung surfactant secretion in neonatal rabbits. Pediatr. Res., 14: 916 (1980).

2. Bergman, B., Hedner, T., and Lundborg, P.: Effects of terbutaline on the pressure volume relationships in the fetal lung. Acta Obstet. Gynecol Scand., 57: 323 (1978).

3. Brown, L. S. and Longmore, W. J.: Adrenergic and cholinergic regulation of lung surfactant secretion in isolated perfused rat lung and in the alveolar type II cell in culture. J. Biol. Chem., 256: 66 (1981).

4. Cabelli, R. J. and Malbon, C. C.: Characterization of $(-)-\left[{ }^{3} \mathrm{H}\right]$ dihydroalprenolol binding sites on isolated rat fat cells. J. Biol. Chem., 254: 8903 (1979).

5. Cheng, J. B., Goldfien, A., Ballard, P. L., and Roberts, J. M.: Glucocorticoids increase pulmonary beta-adrenergic receptors in fetal rabbits. Endocrinology, 107: 1640 (1980).

6. Dobbs, L. G. and Mason, R. J.: Pulmonary alveolar type II cells isolated from rats: release of phosphatidylcholine in response to beta-adrenergic stimulation. J. Clin. Invest., 63: 378 (1979).

7. Enhorning, G., Chamberlain, D., Conteras, C., Burgoyne, R., and Robertson, B Isoxsuprine-induced release of pulmonary surfactant in the rabbit fetus. Am J. Obstet. Gynecol., 129: 197 (1977).

8. Fraser, C. N. and Venter, J. C.: The synthesis of beta-adrenergic receptors in cultured human lung cell: induction by glucocorticoids. Biochem. Biophys. Res. Commun., 94: 390 (1980). 
9. Giannopoulos, G.: Identification and otogeny of beta-adrenergic receptors in fetal rabbit lung. Biochem. Biophys. Res. Commun. 95: 388 (1980)

10. Gross, I., Walker-Smith, G. J., Maniscalco, W. M., Czajka, M. R., Wilson, C. M., and Rooney, S. A.: An organ culture model for study of biochemical development of fetal rat lung. J. Appl. Physiol., 45: 355 (1978).

11. Gross, I., Wilson, C. M., Ingleson, L. D., Brehier, A., and Rooney, S. A.: Fetal lung in organ culture. III. Comparison of dexamethasone, thyroxine and methylxanthines. J. Appl. Physiol., 48: 872 (1980).

12. Haden, W., Olson, E. B., and Zachman, R. D.: Effect of maternal isoxsuprine on fetal rabbit lung biochemical maturation. Am. J. Obstet. Gynecol., 129: 691 (1977).

13. Lawson, E. E., Brown, E. R., Torday, J. S., Madansky, D. L., and Taeusch, H. W.: The effect of epinephrine on tracheal fluid flow and surfactant efflux in fetal sheep. Am. Rev. Respir. Dis., 118: 1023 (1978).

14. Lowry, O. H., Rosebrough, N. J., Farr, A. L., and Randall, R. J.: Protein measurements with the folin phenol reagent. J. Biol. Chem. 193: 265 (1951)

15. Maniscalco, W. M., Wilson, C. M. and Gross, I., Gobran, L., Rooney, S. A., and Warshaw, J.: Development of glycogen and phospholipid metabolism in fetal and newborn rat lung. Biochim. Biophys. Acta, 530: 333 (1978).

16. Maniscalco, W. M., Wilson, C. M., and Gross, I.: Influence of aminophylline and cyclic AMP on glycogen metabolism in fetal rat lung in organ culture. Pediatr. Res., 13: 1319 (1979)

17. Mano, K., Akbarzadek, A., and Townley, R. G.: Effect of hydrocortisone on beta-adrenergic receptors in lung membranes. Life Sci., 25: 1925 (1979).

18. Minneman, K. P., Hegstrand, L. R., and Molinoff, P. B.: The pharmacological specificity of beta- 1 and beta- 2 adrenergic receptors in rat heart and lung in vitro. Mol. Pharmacol., 16: 21 (1979).

Copyright @ 1983 International Pediatric Research Foundation, Inc. $0031-3998 / 83 / 1704-0274 \$ 02.00 / 0$
19. Shapiro, D. L. and Finkelstein, J. N.: The beta-adrenergic receptor of the type II pneumocyte (abstract). Pediatr. Res., 15: 730 (198i)

20. Smith, B. T.: Cell line A 549: a model system for the study of alveolar type II cell function. Am. Rev. Respir. Dis. 115: 285 (1977).

21. U'Prichard, D. C., Bylund, D. B., and Snyder, S. H.: $( \pm)-\left[{ }^{3} \mathrm{H}\right]$ epinephrine and $(-)-\left[{ }^{3} \mathrm{H}\right]$ dihydroalprenolol binding to beta- 1 and beta- 2 nonadrenergic receptors in brain, heart and lung membranes. J. Biol. Chem., 253: 5090 (1978).

22. Weinhold, P. A.: Biosynthesis of phosphatidylcholine during prenatal development of the rat lung. J. Lipid Res., 9: 262 (1968)

23. Whitsett, J. A., Darovec-Beckerman, C., and Adams, K.: Thyroid dependent maturation of beta-adrenergic receptors in the rat lung. Biochem. Biophys. Res. Commun. 97: 913 (1980)

24. Whitsett, J. A., Manton, M. A., Darovec-Beckerman, C., Adams, K. G., and Moore, J. J.: Beta-adrenergic receptors in the developing rabbit lung. Am. J. Physiol., 240: E351 (1981).

25. Williams, M. C. and Mason, R. J.: Development of the type II cell in the fetal rat lung. Am. Rev. Respir. Dis., 115: 37 (1977).

26. The authors gratefully acknowledge the expert technical assistance of Anita Parkhurst and Jann White.

27. Requests for reprints should be addressed to: Dr. William M. Maniscalco, Box 641, University of Rochester School of Medicine, Rochester, NY 14642

28. This research was supported by a grant-in-aid from the American Heart Association and with funds contributed in part by the New York Affiliate of the AHA.

29. Received for publication March 23, 1982

30. Accepted for publication August 5, 1982. 